\title{
Activation of DNA-degrading enzymes during apoptosis
}

\author{
A.I. Scovassi, ${ }^{*}$ A. Torriglia ${ }^{\circ}$ \\ *Istituto di Genetica Molecolare CNR, Pavia, Italy; ' Unité 450 INSERM, Paris, France
}

(C)2003, European Journal of Histochemistry

Cell death by apoptosis requires a precise plan of destruction of DNA and proteins. In this paper, we review the current knowledge on the different DNA-degrading enzymes which are activated in apoptotic cells. The activation of DNases by upstream proteases is also discussed.

Key words: apoptosis, DNases, L-DNase II, proteases, caspases.

Correspondence: Dr. Alicia Torriglia, Unité 450 INSERM, 15, Rue de l'Ecole de Médecine, 75006 Paris, France. Phone: international +33.01.40467850. Fax: international +33.01. 40467865. E-mail: torrigli@infobiogen.fr

Paper accepted on June 19, 2003

European Journal of Histochemistry 2003; vol. 47 issue 3 [Jul-Sept]: 185-194
A balance between cell proliferation and cell death strictly regulates tissue homeostasis. Cell death occurs essentially by two distinct pathways: necrosis and apoptosis. Necrosis, which is caused by non-physiological conditions in the cellular environment, is a passive process characterized by cell swelling, rapid disruption of membrane, random degradation of DNA, organelle damage, dilatation of endoplasmic reticulum and cytoplasm vacuolization. In necrotic cells, membrane integrity is lost, leading to the release of cellular content, with resulting inflammation of surrounding tissues.

The definition of apoptosis was first based on a distinct sequence of morphologic features, described in 1972 by Kerr, Wyllie and Currie. Apoptosis occurs during the embryonic development, in tissue turnover, metamorphosis and atrophy of tissues and organs and during sexual differentiation. In other words, it is involved in many stages of tissue development, providing a way of discarding redundant cellular material (McConkey et al. 1996; Jacobson et al. 1997; Vaux and Korsmeyer 1999). Dysregulation of apoptosis is implicated in the pathogenesis of many human diseases, including neurodegenerative (Honig and Rosenberg 2000) and autoimmune (Rathmell and Thompson 2002) disorders as well as oncogenesis (Lowe and Lin 2000; Tamm et al. 2001; Reed 2001). Apoptosis is an active, energydependent process that is characterized by a series of typical morphological events, such as membrane blebbing, condensation of nuclear chromatin into sharply delineated masses that become marginated against the nuclear membranes, cell shrinkage, internucleosomal DNA fragmentation and protein cleavage (Bratton and Cohen 2001; Bonanno et al., 2002). Among the components of the apoptotic machinery, some factors proved to be evolutionarily conserved from nematodes to mammals (Chinnaiyan 1999; Cain et al. 2002). 


\section{Chromatin}

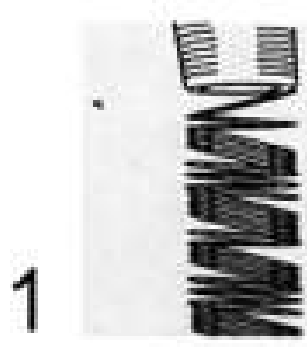

Nuclei
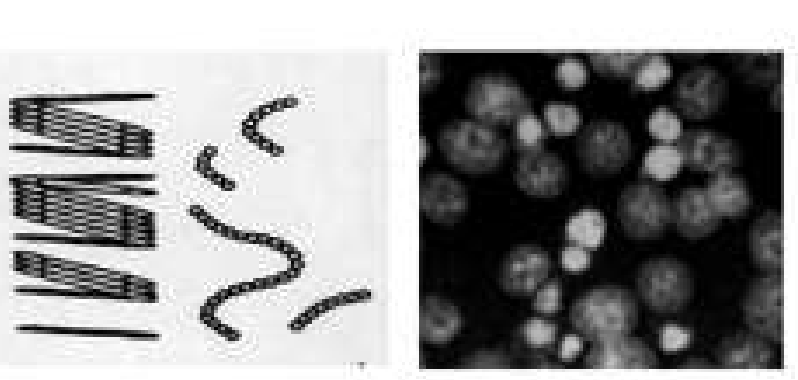

DNA

1234

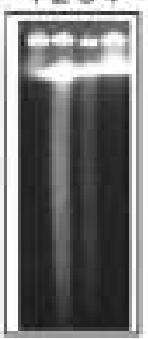

1234
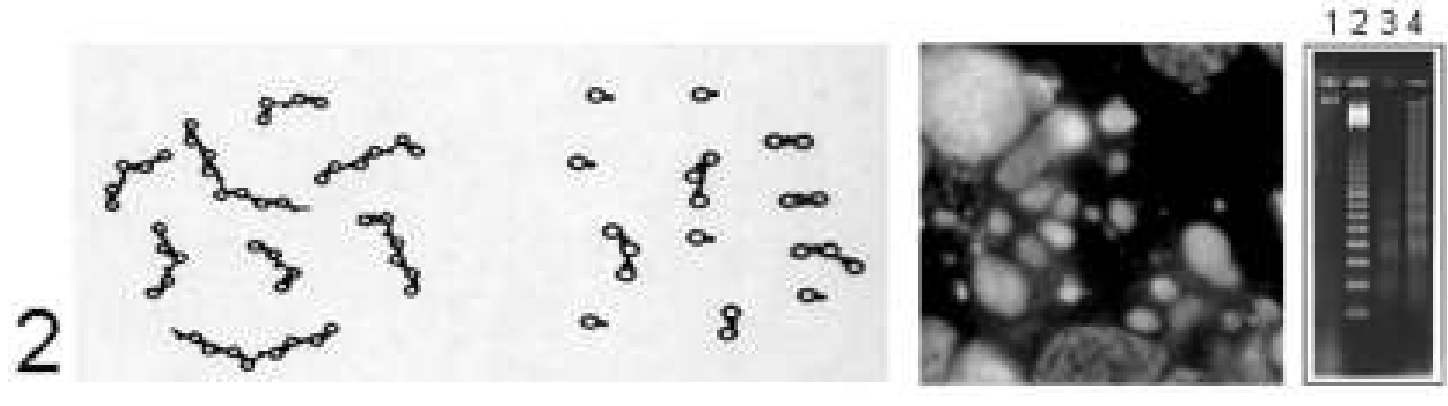

Figure 1. Time-course of DNA degradation in apoptotic cells. Step 1: in nuclei showing chromatin condensation as an incipient sign of apoptosis, DNA is fragmented into high molecular weight fragments (50-300 kb) detectable by pulsed-field gel electrophoresis. Lanes 1,4: control HeLa cells; lanes 2 and 3: HeLa cells treated with $100 \mu \mathrm{M}$ etoposide for $3 \mathrm{~h}$, and further incubated in fresh medium for $3 \mathrm{~h}$ or $24 \mathrm{~h}$, respectively. Step 2: in nuclei showing chromatin fragmentation, internucleosomal DNA degradation occurs, leading to the production of oligonuclesome-sized DNA molecules. A typical DNA ladder is detectable by conventional agarose gel electrophoresis. Lane 1: control HeLa cells; lane 2: markers; lanes 3 and 4: HeLa cells treated with 100 MM etoposide for 3 h, and further incubated in fresh medium for $\mathbf{3}$ h or $\mathbf{2 4} \mathrm{h}$, respectively. Chromatin staining and DNA analysis were performed according to Torriglia et al. (1999).

\section{DNA degradation}

Loss of DNA integrity is a common feature of cell death. As an early event during apoptosis, fragmentation of DNA into high molecular weight (HMW) molecules, ranging from 300 to $50 \mathrm{~kb}$, has been described and monitored by pulsed-field gel electrophoresis (Schwartz and Cantor 1984). Following a precise kinetics of DNA degradation, HMW fragments are further degraded to oligonucleosome-sized DNA molecules. The cleavage of DNA at the internucleosomal region generates DNA fragments with lengths corresponding to multiples of 180 bp, giving rise to a typical "ladder" when analyzed by conventional gel electrophoresis (Wyllie 1980; Wyllie et al. 1980). A further consequence of DNA fragmentation is the presence of free DNA termini, which can be visualized by the TdT-mediated-dUTP nick end labeling (TUNEL) procedure (Gavrieli et al. 1992). The kinetics of DNA degradation is shown in Figure 1.
Internucleosomal DNA fragmentation, a typical hallmark of apoptotic cells (with some exceptions), has been demonstrated to parallel the well-characterized apoptotic morphology in a wide range of situations and cell types (King and Cidlowski 1995). In this respect, the search of DNases, i.e. enzymes cleaving DNA, became a major goal in the characterisation of the apoptotic pathway. This explains the enormous body of literature between 1990 and 1997 concerning endonucleases activation in apoptosis (for reviews, see Montague and Cidlowski 1996; Walker and Sikorska 1997; Counis and Torriglia 2000; Zhang and Xu 2002).

In this paper we will review the current knowledge on the DNases that are activated during apoptosis. A comprehensive review of the literature prompted us to classify these enzymes in three groups, according to their activity dependence (Counis and Torriglia 2000): i) $\mathrm{Ca}^{2+} / \mathrm{Mg}^{2+}$-dependent endonucleases; ii) $\mathrm{Mg}^{2+}$-dependent DNases; iii) 
acid endonucleases or cation-independent DNases. This classification was chosen because many of these enzymes have not been fully characterized and a structural or genetic analysis have not been achieved.

\section{$\mathrm{Ca}^{2+} / \mathrm{Mg}^{2+}$-dependent endonucleases}

Among the different $\mathrm{Ca}^{2+} / \mathrm{Mg}^{2+}$-dependent DNases, DNase I is the best characterized (Peitsch et al. 1993). It has been shown that isolated nuclei of COS cells having little endogenous endonuclease activity, acquire the capability to degrade their DNA into multiples of 180 bp fragments upon transfection of the cells with DNase I cDNA (Polzar et al. 1993). Another DNase implicated in apoptosis is DNase $\mathrm{g}$, which has been characterized at the molecular level (Shiokawa and Tanuma 1998a; 2001). The activity of other nucleases was also investigated; for instance, a $18 \mathrm{kDa}$ nuclease, homologous to cyclophilin, has been isolated from rat thymus (Gaido and Cidlowski 1991; Montague et al. 1994; Montague and Cidlowski 1996). Wyllie and coworkers have isolated from thymocytes a protein of 110-130 kDa, which is closely related to one subunit of topoisomerase Il (Arends et al. 1993). Finally, a caspase 3-activated DNase belongs to this category, i.e. CPAN, the human homologue of CAD (Halenbeck et al. 1998). The human $\mathrm{Ca}^{2+} / \mathrm{Mg}^{2+}$-dependent DNASIL3, a nuclear enzyme which is able to cleave DNA into large molecular weight and oligonucleosomal fragments (Boulares et al. 1999), proved to be regulated in vitro and in vivo by poly(ADP-ribosylation) (Yakovlev et al. 1999; 2000). In this way, the release of DNAS1L3 from poly(ADP-ribosylation)induced inhibition allows it to mediate DNA fragmentation and cell death. Boulares et al. (2001; $2002 a, b)$ demonstrated that cells lacking DFF45, an apoptotic DNA-fragmentation factor, as well as PARP-deficient cells are less sensitive to apoptosis induced by TNF. Interestingly, human osteosarcoma cells depleted of DNASIL3 do not activate etoposide-induced apoptosis. This property was recovered after transfection with exogenous DNASIL3, thus suggesting that loss of expression or inactivation of endonucleases might contribute to reduce cell sensitivity to drug-induced apoptosis.

\section{$\mathrm{Mg}^{2+}$-dependent DNases}

$\mathrm{Mg}^{2+}$-dependent, $\mathrm{Ca}^{2+}$-independent $\mathrm{DN}$ ases were characterized in $\mathrm{CD}^{3} 4^{+}$cells (Kawabata et al.
1993; Anzai et al. 1995). The best-studied enzyme of this class is CAD, which is $\mathrm{Ca} / \mathrm{Mg}$-dependent in human cells but Mg-dependent in mouse. CAD is the first example of a caspase-activated DNase. Enari et al. (1998) purified CAD from mouse lymphoid cells as a protein of $40 \mathrm{kDa}$. During the purification process, it was noted that the extracts from non-apoptotic cells contained a factor that inhibits the CAD. The factor was purified and designated as ICAD (inhibitor of CAD), which is a substrate of caspase 3 (Enari et al. 1998), thus indicating that the activation of endonucleases is downstream caspases. The same factors were purified independently by Liu (called DFF) and Halenbeck (called CPAN) from HeLa and Jurkat cells, respectively (Halenbeck et al. 1998; Liu et al. 1998). DFF is composed of two subunits of 45- and 40kDa (DFF-45 and DFF-40). Caspase 3 cleaves DFF-45 and generates a DNase activity, so that DFF-45 is the equivalent of ICAD and DFF-40 is the equivalent of CAD. As well as inhibiting CAD, ICAD seems to have chaperone properties in regard of $C A D$, since in its absence no active CAD can be produced (Sakahira et al. 2000). CAD and ICAD are expressed in most tissues and cell lines undergoing rapid DNA fragmentation after apoptotic stimuli (Mukae et al. 1998). In contrast, some cell types like fibroblasts and nerve cell lines have low levels of these proteins. Zhang et al. (1999) showed in thymocytes from ICAD-null mice no DNA fragments upon exposure to apoptotic stimuli, thus demonstrating that CAD/ICAD system regulates DNA fragmentation.

\section{Acid endonucleases or cation-independent DNases}

Eastman's group was the first to implicate acid DNases in DNA fragmentation during apoptosis (Eastman and Barry 1992; Barry and Eastman 1993; Barry et al. 1993). Other authors showed that intracellular acidification induces DNA cleavage that may be catalyzed by these types of DNases (Gottlieb et al. 1995; 1996; Collins et al. 1996; Leaseholder et al. 1996; Furlong et al. 1997). Different groups have cloned a DNase II (Baker et al. 1998; Krieser and Eastman 1998; 2000; Shiokawa and Tanuma 1998b; Wang et al. 1998; Yasuda et al. 1998; Lyon et al. 2000) that seems to be a secreted enzyme (Wang et al. 1998). Recent work using knock-out mice for DNase II indicates that this enzyme is important for housekeeping during erythroid cell differentiation and DNA clear- 


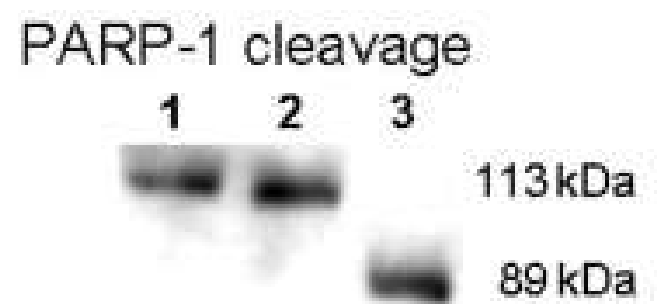

\section{L-DNase II activation}

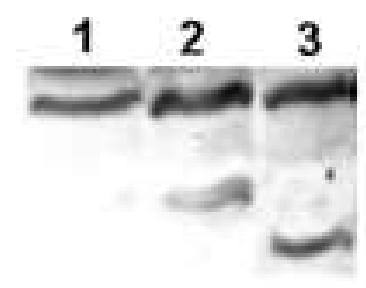

$42 \mathrm{kDa}$

$35 \mathrm{kDa}$ $27 \mathrm{kDa}$

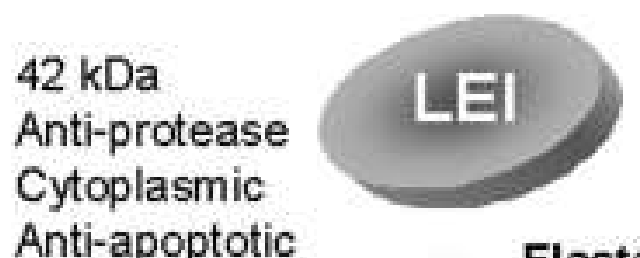

Anti-apoptotic

\section{Elastase} Cathepsin B Cathepsin G AP24

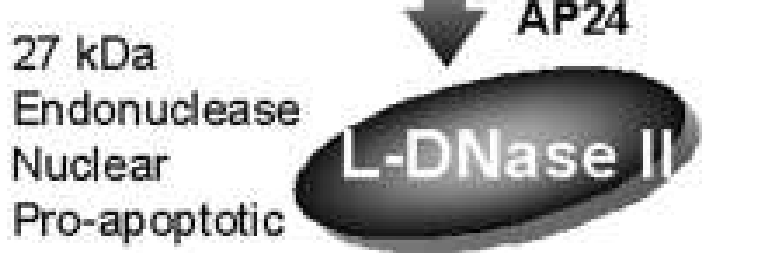

Figure 2. Conversion of LEI (Leukocyte Elastase Inhibitor) into L-DNase II in apoptotic cells. Total extracts from long term-cultured HeLa cells (i.e. cells grown in the same medium for 8 days) were analyzed by western blot for PARP-1 cleavage and for L-DNasell activation. Lane 1: control cells; lane 2: attached cells recovered after 8 days in culture; lane 3: floating, apoptotic cells recovered after 8 days in culture. Apoptotic cells (lane 3) are characterized by the presence of PARP-1 cleavage product of 89 kDa, and of the 27 kDa L-DNase II. Western blot analysis was performed according to Torriglia et al. (1999). Right panel shows the features of LEl and L-DNase II, and the possible mechanisms regulating the conversion of LEI into L-DNase II.

ance, but not for cellular apoptosis itself (Kawane et al. 2001; Krieser et al. 2002). In 1999, an acid nuclease, activated during apoptosis in HeLa cells, was found (Famulski et al. 1999). This nuclease is active in acetate buffer and insensitive to $\mathrm{Zn}^{2+}$, and its activation is caspase-independent. In our laboratory, we have demonstrated the involvement of DNase II in chick lens cell terminal differentiation (Torriglia et al. 1995), which is characterized by the disappearance of nuclei from lens fiber cells. The process of nuclear degradation shares many features with nuclei of apoptotic cells (Counis et al. 1998), even if DNA fragments are not a good substrate for TUNEL reaction (Chaudun et al. 1994). Since DNase II cuts DNA and produces 3'P termini, we evaluated the involvement of this enzyme in the apoptotic pathway and we showed that antibodies directed against DNase II inhibit DNA degradation in isolated lens cell nuclei. Remarkably, DNase II is located in the cytoplasm of undifferentiated cells and only becomes nuclear in cells undergoing differentiation.

\section{L-DNase II}

Recently, we have characterized a protein with a DNase II activity, which is different from the above described DNase Il (Torriglia et al. 1998). In vitro this DNase, called L-DNase II, has the properties of a DNase II, with optimal activity at pH 5.75. In contrast to the other DNase II described above, it keeps the $50 \%$ of its activity at pH 7.4 (Counis et al. 1998). L-DNase II is derived from LEI (Leukocyte Elastase Inhibitor) by an acid-dependent post-translational modification or by digestion with elastase. In vitro experiments, using purified recombinant LEI, showed that the native form has no activity on purified nuclei whereas its posttranslationally activated form induces picnosis and DNA degradation in isolated nuclei. The conversion of LEI into L-DNase II is promoted by intracellular acidification (Altairac et al. 2003a). In different cell lines, we showed an increased expression and a nuclear translocation of L-DNase II during apoptosis (Torriglia et al. 1999; Belmokhtar et al. 2000; Gorrini et al. 2003). In Figure 2, western blot analysis of the conversion of LEI into L-DNase in apoptotic cells is reported. A typical example of intracellular redistribution of L-DNase II during apoptosis is shown in Figure 3.

\section{The activation of DNases during apoptosis}

The apoptotic sequence proceeds according to a precise plan of destruction of DNA and proteins. As above reviewed, DNA can be degraded by many 


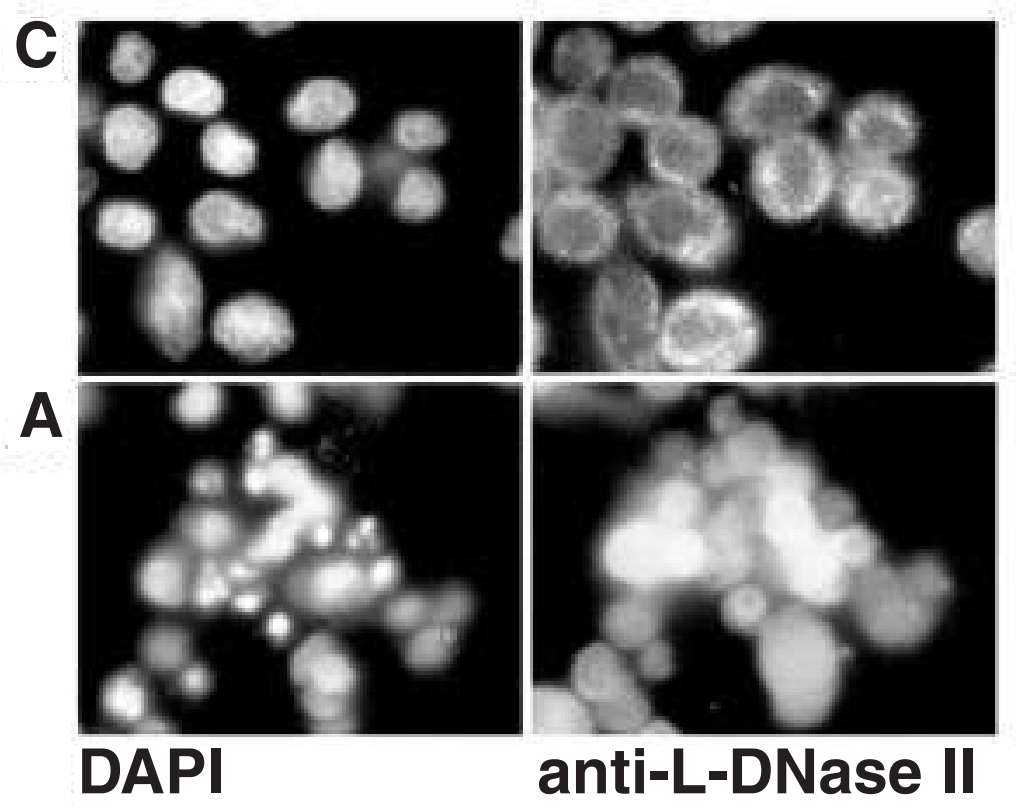

Figure 3. Translocation of L-DNase II from the cytoplasm to the nucleus of apoptotic HeLa cells. In control cells (C), L-DNase II shows an extra-nuclear localization. In long termcultured cells, L-DNase II immunofluorescence is visible in the nuclear compartment. Immunofluorescence was performed according to Torriglia et al. (1999).
DNases/endonucleases, possibly following different strategies, depending on the cell type and the nature of the stimulus. The activity of DNA-degrading enzymes is in turn regulated by proteases. Consequently, CAD is activated after cleavage of ICAD, its inhibitor, by caspase 3 (Enari et al. 1998). If we assume the other endonucleases activated during apoptosis behave in the same way, a class of non caspase-proteases should exist and activate, directly or not, other endonucleases. This seems to be the case, since other proteases have been implicated in apoptosis.

\section{The proteases activated during apoptosis}

\section{Caspases}

PARP-1, the best marker of proteolysis during apoptosis (Scovassi and Poirier, 1999; Soldani and Scovassi, 2002), proved to be cleaved in cells treated with different drugs (Kaufmann et al. 1993; Soldani et al., 2001), by a protease resembling ICE (prICE; Lazebnik et al. 1994). This protease was further identified as caspase 3 (Nicholson et al. 1995; Tewari et al. 1995; Casciola-Rosen et al. 1996). At least 14 mammalian caspases have been described (Chang and Yang 2000). Caspases exist in the cell as pro-caspases, whose activation requires a proteolytic event and occurs in a cascade-like way. In respect to the time-course of their activity during the apoptotic pathway, they can act as initiator or effector caspases. Once activated, the initiator caspases process downstream caspases to promote the cleavage of a number of substrates (Salvesen and Dixit 1997; Thornberry and Lazebnik 1998; Chang and Yang 2000; Cain et al. 2002). The use of inhibitors and gene knock-out strategy revealed that caspases have overlapping roles and that their function is so essential that they are redundant within the cell. Many targets of caspases have been described, including structural proteins, enzymes and cell cycle factors. That caspase inhibition does not abolish cell demise, suggests the existence of a caspase-independent apoptotic pathway (Leist and Jäättelä 2001). In this respect, a number of alternative proteases have been described to be active during apoptosis, as reported below.

\section{Calpains}

Calpains are non-lysosomal $\mathrm{Ca}^{2+}$-dependent cysteine proteases structurally unrelated to caspases. Ubiquitous cytoplasmic calpains exist as two isoforms, $\mu$-calpain and m-calpain, and are constitutively expressed. Their possible involvement in apoptosis was first suggested by Sarin et al. (1993) and Robert-Lewis et al. (1993) and has been reported for several cells, even if little is known about their exact role. By the use of calpain inhibitor acetylcalpastatin 27-peptide, it has been clearly demonstrated that calpains are required after a number of apoptogenic stimuli (Sarin et al. 1994; Squier et al. 1994; 1999; Squier and Cohen 1997), including during calcium-dependent apoptosis (Ravid et al. 
1994; Gil Parrado et al. 2002). Interestingly, the overexpression of calpastatin gene reduces dystrophic pathology, thus suggesting that calpain inhibition might provide a therapeutic strategy for this disorder (Spencer and Mellgren 2002), as well as for Alzheimer (Di Rosa et al. 2002) and Huntington (Goffredo et al. 2002) diseases. Calpain substrates are cytoskeleton proteins including fodrin, membrane receptors and transporters, and steroid receptors (Chan and Mattson 1999). It is noteworthy that $\mathrm{Bcl}-\mathrm{xL}$ is converted by calpain from the anti-apoptotic into the pro-apoptotic form (Nakagawa and Yuan 2000) and that Bid cleavage promotes cytochrome $\mathrm{c}$ release (Chen et al. 2001). By proteolytic degradation, calpains also contribute to the regulation of P53 (Pariat et al. 1997) and cMyc (Small et al. 2002) levels during apoptosis. Remarkably, a crosstalk between calpains and caspases during apoptosis was postulated. In fact, calpain is implicated in caspase-7 activation during $B$ cell clonal deletion (Ruiz-Vela et al. 1999) and is responsible for cleaving pro-caspase 12 to generate active caspase-12 (Nakagawa and Yuan 2000; Neumar et al. 2003). To date no relationship has been found between the activation of calpains and a particular endonuclease.

\section{Cathepsins}

The cathepsin protease family includes cysteine, aspartate and serine proteases (Chapman et al. 1997). Cysteine cathepsins $L$ and $B$, together with the aspartic protease cathepsin $D$, are the most abundant lysosomal proteases and have been clearly correlated with apoptosis (Roberts et al. 1999; Tsukuba et al. 2000; Uchiyama 2001). Genetic evidence for the role of cysteine cathepsins in apoptosis has been provided by studies showing resistance against TNF-induced apoptosis in mice lacking cathepsin B (Roberts et al. 1999; Guicciardi et al. 2000; Felbor et al. 2002), and massive death in the brains of mice that lack cathepsin inhibitor cystatin B (Lieuallen et al. 2001) and in cells treated with cathepsin inhibitors (Castino et al. 2002). Cathepsins are translocated from lysosomes to the cytosol and/or to the nucleus before the appearance of apoptotic morphological changes. Some of them are involved in caspase-dependent apoptosis (Turk et al. 2000; Roberg et al. 2002) and cleave crucial factors, such as Bid (Stoka et al. 2001) and Brm (Biggs et al. 2001).

\section{Granzymes}

Granzymes, a family of serine proteases, are packaged in the granules of CTLs and natural killer cells (Trambas and Griffiths 2003). Granzyme B, the most powerful pro-apoptotic member of the family, after intracellular delivery by perforin induces a proteolytic cascade by acting as an apical caspase, thus processing a number of key caspases (Atkinson et al. 1998; Barry et al. 2000). Granzyme B is also able to cleave and activate directly the pro-apoptotic factor Bid (Pinkoski et al. 2001; Sutton et al. 2000) and other proteins in a caspase-independent death pathway. In fact, in the presence of caspase inhibitors, granzyme B might cause cell death independently of the caspases, even with a slower kinetics. Death induced by granzyme $A$ is associated with DNA single-strand breaks created by a granzyme A-activated DNase (Beresford et al. 2001; Fan et al. 2003).

\section{Serine proteases}

Other serine proteases different from granzymes have been described to play a role in cell death: Omi/Htra2, a mitochondrial protease that upon induction of apoptosis is released to the cytoplasm, is involved in both caspase-dependent and -independent apoptosis (Hegde et al. 2002; Cilenti et al. 2003; Jin et al. 2003). The $24 \mathrm{kDa}$ apoptotic protease (AP24) is a serine protease with elastase-like activity that is activated during TNF $\alpha$ - or UV lightinduced apoptosis and stimulates in vitro internucleosomal DNA fragmentation in isolated nuclei (Wright et al. 1997; 1998a; 1998b). We recently described the interaction between AP24 and LEI/L-DNase II (Altairac et al. 2003b) and showed that L-DNase II is activated in U937 cells treated with $T N F \alpha$, i.e. in an apoptotic model recruiting AP24. Remarkably, we found that LDNase II activity is suppressed when apoptosis is attenuated by an AP24 inhibitor, carbobenzoxyAla-Ala-borophe (DK120).

\section{DNases and the control of apoptosis}

DNA degradation during apoptosis has often been considered a housekeeping task in the cell. However, recent findings show that DNA degradation can also control apoptosis. Parrish et al. (2001), while searching for new cell death-inducing factors that are released from cells primed to die, purified endoG, a previously described mitochondrial enzyme with a proposed role in the replication of 


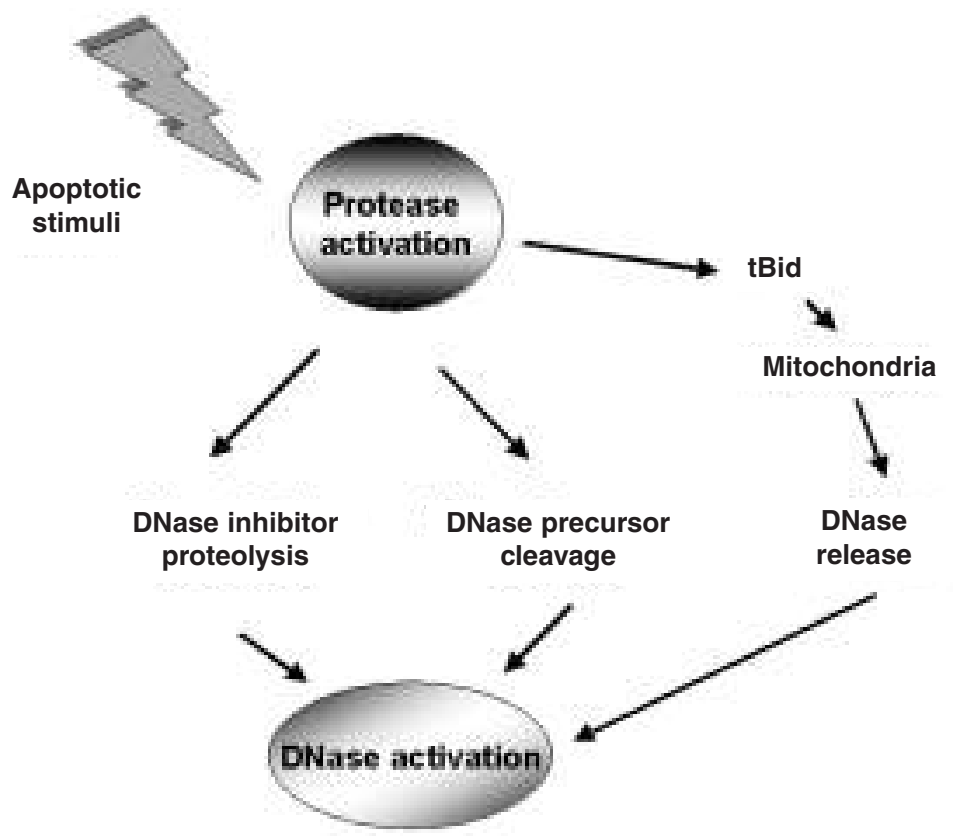

Figure 4. Cross-talk between proteases and DNases during apoptosis. Active proteases, including caspases, calpains, cathepsins, serine proteases, can promote the activation of DNases in different ways, i.e. by cleaving a DNase precursor (LEI/IL-DNase II) or a DNase inhibitor (CAD/ICAD; PARP-1/NAS1L3) or by releasing DNases from mitochondria (endoG). mitochondrial DNA. These authors suggested that endoG not only participates in the deconstruction of apoptotic cells, but can also contribute to the actual killing process. These authors identified the genes that, when mutated, protect cells from apoptosis. Among them, cps-6, (the nematode counterpart of endoG) not only promotes DNA degradation, but also contributes to cell killing. Its loss slightly increased cell survival in many genetic backgrounds of $C$. elegans. These results suggest that DNA degradation and therefore endonucleases have a role in the control of apoptosis, perhaps because of the importance of their housekeeping function.

\section{Conclusions}

Over the two decades following the pioneering work of Kerr et al. (1972), it was generally accepted that different apoptotic stimuli activate a common apoptotic pathway. This idea was supported essentially by the fact that the apoptotic process is highly conserved from the morphological point of view, and because of the discovery of caspases as common executioners of apoptosis. More recently, the discovery of many DNases involved in DNA degradation in different apoptotic systems, and of proteases other than caspases, have shown that distinct molecular pathways lead to apoptosis. In this respect, it is now widely accepted that caspasedependent and -independent pathways exist, leading to alternative execution systems. Factors involved in caspase-independent apoptosis are under characterization (Nicotera 2001; Mathiasen and Jäättelä 2002; Jäättelä and Tschopp 2003). To date, a precise link between endonucleases and the non caspase-proteases has not been stated, except for LEI/L-DNase II, that may be activated by AP24, a serine protease.

From these facts, an intriguing question arises: why would a cell need more than one nuclease to digest its DNA? One hint might come from the different ways of regulation of such enzymes (Figure 4). In living cells, CAD is sequestered in an inactive complex, in a form bound to its inhibitory subunit (known as ICAD or DFF45). By contrast, endoG is activated by a change in its subcellular localization and L-DNase II derives from a protein which has another function (LEI is a protease inhibitor). The existence of redundant pathways leading to cell death may help when caspase activation is limited or compromised, as it might be the case, for example, during viral infection.

\section{Acknowledgements}

This work was partially supported by the CNR/INSERM program no. 132.22.2, the Italian MIUR (FIRB Project RBNE0132MY) and by Rétina France. The authors are in debt with people involved in this research in their laboratories: S. Chahory, M.F. Counis, Y. Courtois, M. Denegri, E. Martin, L. Padron and G. Sidoli. We thank Dr. J.R. Smith for editing the English version. 


\section{References}

Alnemri ES, Livingston DJ, Nicholson DW, Salvesen G, Thornberry NA, Wong WW et al. Human ICE/CED-3 protease nomenclature. Cell 1996; 87:171.

Altairac S, Zeggai S, Perani P, Courtois Y, Torriglia A. Apoptosis induced by $\mathrm{Na}(+) / \mathrm{H}(+)$ antiport inhibition activates the LEI/LDNase II pathway. Cell Death Differ 2003a; 10:548-57.

Altairac S, Wright SC, Courtois Y, Torriglia A. L-DNase II activation by the $24 \mathrm{kDa}$ apoptotic protease (AP24) in TNFa-induced apoptosis. Cell Death Differ 2003b; in press.

Anzai NH, Kawabata $T$, Hirama H, Masutani $Y$, Ueda $Y$, Yoshida et al. Types of nuclear endonuclease activity capable of inducing internucleosomal DNA fragmentation are completely different between human CD34+ cells and their granulocytic descendants. Blood 1995; 86:917-23.

Arends MJ, McGregor AH, Toft NJ, Brown EJ, Wyllie AH. Susceptibility to apoptosis is differentially regulated by c-myc and mutated $\mathrm{Ha}$-ras oncogenes and is associated with endonuclease availability. Br J Cancer 1993; 68:1127-33.

Atkinson EA, Barry M, Darmon AJ, Shostak I, Turner PC, Moyer RW et al. Cytotoxic T lymphocyte-assisted suicide. Caspase 3 activation is primarily the result of the direct action of granzyme $\mathrm{B}$. J Biol Chem 1998; 273:21261-6.

Baker KP, Baron WF, Henzel WJ, Spencer SA. Molecular cloning and characterization of human and murine DNase II. Gene 1998; 215:281-9.

Barry M, Heibein JA, Pinkoski MJ, Lee SF, Moyer RW, Green DR, et al. Granzyme B short-circuits the need for caspase 8 activity during granule-mediated cytotoxic T-lymphocyte killing by directly cleaving Bid. Mol Cell Biol 2000; 20:3781-94.

Barry MA, Eastman A. Identification of deoxyribonuclease II as an endonuclease involved in apoptosis. Arch Biochem Biophys 1993 300:440-50.

Barry MA, Reynolds JE, Eastman A. Etoposide-induced apoptosis in human HL-60 cells is associated with intracellular acidification. Cancer Res 1993; 53:2349-57.

Belmokhtar CA, Torriglia A, Counis MF, Courtois Y, Jacquemin-Sablon A, Segal-Bendirdjian E. Nuclear translocation of a leukocyte elastase Inhibitor/Elastase complex during staurosporine-induced apoptosis: role in the generation of nuclear L-DNase II activity. Exp Cell Res 2000; 254:99-109.

Beresford PJ, Zhang D, Oh DH, Fan Z, Greer EL, Russo M et al. Granzyme A activates an endoplasmic reticulum-associated caspase-independent nuclease to induce single-stranded DNA nicks. J Biol Chem 2001; 276:43285-93.

Biggs JR, Yang J, Gullberg U, Muchardt C, Yaniv M, Kraft AS The human brm protein is cleaved during apoptosis: the role of cathepsin G. Proc Natl Acad Sci USA 2002; 98:3814-9

Bonanno E, Tagliafierro G, Carla EC, Montinari MR, Pagliara $P$, Mascetti $G$, Spagnoli $L G$, Dini $L$ Synchronized onset of nuclear and cell surface modifications in U937 cells during apoptosis. Eur J Histochem 2002; 46: 61-74

Boulares AH, Yakovlev AG, Ivanova V, Stoica BA, Wang G, Iyer $S$ et al. Role of poly(ADP-ribose) polymerase (PARP) cleavage in apoptosis. J Biol Chem 1999a; 274:22932-40.

Boulares AH, Zoltosky AJ, Contreras FJ, Yakovlev A, Xu M, Smulson ME. Roles of DNA fragmentation factor and poly(ADP-ribose) polymerase in an amplification phase of tumor necrosis factorinduced apoptosis. J Biol Chem 2001b; 276:38185-92.

Boulares AH, Zoltosky AJ, Contreras FJ, Yakovlev AG, Yoshihara K, Smulson ME. Regulation of DNASIL3 endonuclease activity by poly(ADP-ribosyl)ation during etoposide-induced apoptosis. J Biol Chem 2002; 277:372-8.

Boulares AH, Zoltosky AJ, Sherif ZA, Yakovlev A, Smulson ME. Roles of DNA fragmentation factor and poly(ADP-ribose) polymerase-1 in sensitization of fibroblasts to tumor necrosis factor-induced apoptosis. Biochem Biophys Res Commun 2002; 290:796-801.

Bratton SB, Cohen GM. Apoptotic death sensor: an organelle's alter ego? Trends Pharmacol Sci 2001; 22:306-15.

Cain K, Bratton SB, Cohen GM. The Apaf-1 apoptosome: a large caspase-activating complex. Biochimie 2002; 84: 203-14.

Canitrot $Y$, Frit $P$, Salles B. Deficient apoptotic process in cisplatin- resistant L1210 cells cannot account for the cellular response to various drug treatments. Biochem Biophys Res Commun 1997; 234 :573-7.

Casciola-Rosen L, Nicholson DW, Chong T, Rowan KR, Thornberry NA, Miller DK et al. Apopain/CPP32 cleaves proteins that are essential for cellular repair: a fundamental principle of apoptotic death. $J$ Exp Med 1996; 183:1957-64.

Castino R, Pace D, Demoz M, Gargiulo M, Ariatta C, Raiteri E et al. Lysosomal proteases as potential targets for the induction of apoptotic cell death in human neuroblastomas. Int J Cancer 2002; 97:775-9.

Chan SL, Mattson MP Caspase and calpain substrates: roles in synaptic plasticity and cell death. J Neurosci Res 1999; 58:167-90.

Chang HY, Yang X. Proteases for cell suicide: functions and regulation of caspases. Microbiol Mol Biol Reviews 2000; 64:821-46.

Chapman, HA, Riese RJ, Shi GP. Emerging roles for cysteine proteases in human biology. Annu Rev Physiol 1997; 59:63-88.

Chaudun E, Arruti C, Courtois Y, Ferrag F, Jeanny JC, Patel BN et al. DNA strand breakage during physiological apoptosis of the embryonic chick lens: free $3^{\prime} \mathrm{OH}$ end single strand breaks do not accumulate even in the presence of a cation-independent deoxyribonuclease. J Cell Physiol 1994; 158:354-64.

Chen M, He H, Zhan S, Krajewski S, Reed JC, Gottlieb RA. Bid is cleaved by calpain to an active fragment in vitro and during myocardial ischemia/reperfusion. J Biol Chem 2001; 276:30724-8.

Chinnaiyan AM. The apoptosome: heart and soul of the cell death machine. Neoplasia 1999; 1: 5-15.

Cilenti L, Lee Y, Hess S, Srinivasula S, Park KM, Junqueira D et al. Characterization of a novel and specific inhibitor for the pro-apoptotic protease 0mi/HtrA2. J Biol Chem 2003; 278:11489-94.

Collins MK, Furlong IJ, Malde P, Ascaso R, Oliver J, Lopez Rivas A. An apoptotic endonuclease activated either by decreasing $\mathrm{pH}$ or by increasing calcium. J Cell Sci 1996; 109:2393-9.

Counis MF, Chaudun E, Arruti C, Oliver J, Sanwal M, Courtois Y et al. Analysis of nuclear degradation during lens cell differentiation. Cell Death Differ 1998; 5:251-61.

Counis MF, Torriglia A. DNases and apoptosis. Biochem Cell Biol 2000; 78:405-14.

Di Rosa G, Odrijin T, Nixon RA, Arancio 0. Calpain inhibitors: a treatment for Alzheimer's disease. J Mol Neurosci 2002; 19:135-41.

Eastman A, Barry MA. The origins of DNA breaks: a consequence of DNA damage, DNA repair, or apoptosis? Cancer Invest 1992; 10:229-40

Enari M, Sakahira H, Yokoyama H, Okawa K, Iwamatsu A, Nagata S. A caspase-activated DNase that degrades DNA during apoptosis, and its inhibitor ICAD. Nature 1998; 391:43-50.

Famulski KS, Macdonald D, Paterson MC, Sikora E. Activation of a low $\mathrm{pH}$-dependent nuclease by apoptotic agents. Cell Death Differ $1999 ; 6: 281-9$

Fan Z, Beresford PJ, Oh DY, Zhang D, Lieberman J Tumor suppressor NM23-HI is a granzyme A-activated DNase during CTL-mediated apoptosis, and the nucleosome assembly protein SET is its inhibitor. Cell 2003; 112:659-72.

Felbor U, Kessler B, Motes W, Goebel HH, Ploegh HL, Bronson RT, Olsen BR Neuronal loss and brain atrophy in mice lacking cathepsins B and L. Proc Natl Acad Sci USA 2002; 99:7883-8.

Furlong IJ, Ascaso R, Lopez Rivas A, Collins MK. Intracellular acidification induces apoptosis by stimulating ICE-like protease activity. J Cell Sci 1997; 110:653-61.

Gaido ML, Cidlowski JA. Identification, purification, and characterization of a calcium-dependent endonuclease (NUC18) from apoptotic rat thymocytes. NUC18 is not histone H2B. J Biol Chem 1991; 266:18580-5.

Gavrieli $Y$, Sherman $Y$, Ben-Sasson SA. Identification of programmed cell death in situ via specific labeling of nuclear DNA fragmentation. J Cell Biol 1992; 119:493-501.

Gil-Parrado S, Fernández-Montalván A, Assfalg-Machleidt I, Popp 0, Bestvater $F$, Holloschi A et al. Ionomycin-activated calpain triggers apoptosis. J Biol Chem 2002; 277:27217-26.

Goffredo D, Rigamonti D, Tartari M, De Micheli A, Verderio C, Matteoli $\mathrm{M}$ et al. Calcium-dependent cleavage of endogenous wild-type Huntington in primary cortical neurons. J Biol Chem 2002; 277:39594-8

Gorrini C, Donzelli M, Torriglia A, Supino R, Brison 0, Bernardi R et 
al. Effect of apoptogenic stimuli on colon carcinoma cell lines with a different c-myc expression level. Int J Mol Med 2003; 11:737-42.

Gottlieb RA, Giesing HA, Engler RL, Babior BM. The acid deoxyribonuclease of neutrophils: a possible participant in apoptosis-associated genome destruction. Blood 1995; 86:2414-8.

Gottlieb RA, Nordberg J, Skowronski E, Babior BM. Apoptosis induced in Jurkat cells by several agents is preceded by intracellular acidification. Proc Natl Acad Sci USA 1996; 93:654-8.

Guicciardi ME, Deussing J, Miyoshi H, Bronk SF, Svingen PA, Peters $C$ et al. Cathepsin B contributes to TNF-alpha-mediated hepatocyte apoptosis by promoting mitochondrial release of cytochrome $\mathrm{c}$. $J$ Clin Invest 2000 106:1127-37.

Halenbeck R, MacDonald H, Roulston A, Chen TT, Conroy L, Williams LT. CPAN, a human nuclease regulated by the caspase-sensitive inhibitor DFF45. Curr Biol 1998; 8:537-40.

Hegde R., Srinivasula SM, Zhang Z, Wassell R, Mukattash R, Cilenti $\mathrm{L}$, et al. Identification of $0 \mathrm{mi} / \mathrm{HtrA} 2$ as a mitochondrial apoptotic serine protease that disrupts inhibitor of apoptosis protein-caspase interaction. J Biol Chem 2002; 277:432-8.

Honig LS, Rosenberg RN. Apoptosis and neurologic disease. Am J Med 2000; 108:317-30.

Jäättelä M, Tschopp J. Caspase-independent cell death in T lymphocytes. Nature Immunol 2003; 4:416-23.

Jacobson MD, Weil M, Raff MC. Programmed cell death in animal development. Cell 1997; 88:347-54.

Jin S, Kalkum M, Overholtzer M, Stoffel A, Chait BT, Levine AJ. CIAP1 and the serine protease HTRA2 are involved in a novel p53dependent apoptosis pathway in mammals. Genes Dev 2003; 17:359-67.

Kaufmann SH, Desnoyers S, Ottaviano Y, Davidson NE, Poirier GG. Specific proteolytic cleavage of poly(ADP-ribose) polymerase: an early marker of chemotherapy-induced apoptosis. Cancer Res 1993; 53:3976-85.

Kawabata H, Anzai N, Masutani H, Hirama T, Yoshida Y, Okuma M. Detection of $\mathrm{Mg}(2+)$-dependent endonuclease activity in myeloid leukemia cell nuclei capable of producing internucleosomal DNA cleavage. Biochem Biophys Res Commun 1993; 191:247-54.

Kawane K, Fukuyama H, Kondoh G, Takeda J, Ohsawa Y, Uchiyama Y et al. Requirement of DNase II for definitive erythropoiesis in the mouse fetal liver. Science 2001; 292:1546-9.

Kerr JF, Wyllie AH, Currie AR. Apoptosis: a basic biological phenomenon with wide-ranging implications in tissue kinetics. $\mathrm{Br} \mathrm{J}$ Cancer $1972 ; 26: 239-57$

King KL, Cidlowski JA. Cell cycle and apoptosis: common pathways to life and death. J Cell Biochem 1995; 58:175-80.

Krieser RJ, Eastman A. The cloning and expression of human deoxyribonuclease II. A possible role in apoptosis. J Biol Chem 1998; 273: 30909-14.

Krieser RJ, Eastman A. Deoxyribonuclease II: structure and chromosomal localization of the murine gene, and comparison with the genomic structure of the human and three C. elegans homologs. Gene 2000; 252:155-62.

Krieser RJ, MacLea KS, Longnecker DS, Fields JL, Fiering S, Eastman A. Deoxyribonuclease IIalpha is required during the phagocytic phase of apoptosis and its loss causes perinatal lethality. Cell Death Differ 2002; 9:956-62.

Lazebnik YA, Kaufmann SH, Desnoyers S, Poirier GG, Earnshaw WC. Cleavage of poly(ADP-ribose) polymerase by a proteinase with properties like ICE. Nature 1994; 371:346-7.

Leist M, Jäättelä M. Four deaths and a funeral: from caspases to alternative mechanisms. Nature Rev Mol Cell Biol 2002; 2:589-98.

Lieuallen K, Pennacchio LA, Park M, Myers RM, Lennon GG. Cystatin B-deficient mice have increased expression of apoptosis and glial activation genes. Hum Mol Genet 2001; 10:1867-71.

Liu X, Li P, Widlak P, Zou H, Luo X, Garrard WT et al. The 40-kDa subunit of DNA fragmentation factor induces DNA fragmentation and chromatin condensation during apoptosis. Proc Natl Acad Sci USA 1998; 95:8461-6.

Lowe SW, Lin AW. Apoptosis in cancer. Carcinogenesis 2000; 21: 48595.

Lyon CJ, Evans CJ, Bill BR, Otsuka AJ, Aguilera RJ. The C. elegans apoptotic nuclease NUC-1 is related in sequence and activity to mammalian DNase II. Gene 2000; 252:147-54.

Mathiasen IS, Jäättelä M. Triggering caspase-independent cell death to combat cancer. Trends Mol Med 2002; 8:212-20.

McConkey DJ, Zhivotovsky B, Orrenius S. Apoptosis-molecular mechanisms and biomedical implications. Mol Aspects Med 1996; 17:1110.

Meisenholder GW, Martin SJ, Green DR, Nordberg J, Babior BM, Gottlieb RA. Events in apoptosis. Acidification is downstream of protease activation and BCL-2 protection. J Biol Chem 1996; 271:16260-2.

Montague JW, Cidlowski JA. Cellular catabolism in apoptosis: DNA degradation and endonuclease activation. Experientia 1996; 52:957-62.

Montague JW, Gaido ML, Frye C, Cidlowski JA. A calcium-dependent nuclease from apoptotic rat thymocytes is homologous with cyclophilin. Recombinant cyclophilins A, B, and C have nuclease activity. J Biol Chem 1994; 269:18877-80.

Mukae N, Enari M, Sakahira H, Fukuda Y, Inazawa J, Toh $\mathrm{H}$ et al. Molecular cloning and characterization of human caspase-activated DNase. Proc Natl Acad Sci USA 1998; 95:9123-8.

Nakagawa T, Yuan J. Cross-talk between two cysteine protease families. Activation of caspase-12 by calpain in apoptosis. J Cell Biol 2000; 150:887-94.

Neumar RW, Xu YA, Gada H, Guttmann RP, Siman R Cross-talk between calpain and caspase proteolytic systems during neuronal apoptosis. J Biol Chem 2003; 278:14162-7.

Nicholson DW, Ali A, Thornberry NA, Vaillancourt JP, Ding CK, Gallant $\mathrm{M}$ et al. Identification and inhibition of the ICE/CED-3 protease necessary for mammalian apoptosis. Nature 1995; 376:3743.

Nicotera P. Apoptosis and age-related disorders: role of caspasedependent and caspase-independent pathways. Toxicol Lett 2002; 127:189-95.

Pariat M, Carillo S, Molinari M, Salvat C, Debussche L, Bracco L et al. Proteolysis by calpains: a possible contribution to degradation of p53. Mol Cell Biol 1997; 17:2806-15.

Parrish J, Li L, Klotz K, Ledwich D, Wang X, Xue D. Mitochondrial endonuclease $G$ is important for apoptosis in $C$. elegans. Nature 2001; 412:90-4.

Peitsch MC, Polzar B, Stephan H, Crompton T, MacDonald HR, Mannherz HG et al. Characterization of the endogenous deoxyribonuclease involved in nuclear DNA degradation during apoptosis (programmed cell death). EMBO J 1993; 12:371-7.

Pinkoski MJ, Waterhouse NJ, Heibein JA, Wolf BB, Kuwana $T$, Goldstein JC et al. Granzyme B-mediated apoptosis proceeds predominantly through a Bcl-2-inhibitable pathway. J Biol Chem 2001; 276:12060-7.

Polzar B, Peitsch MC, Loos R, Tschopp J, Mannherz HG. Overexpression of deoxyribonuclease I (DNase I) transfected into COS-cells: its distribution during apoptotic cell death. Eur J Cell Biol 1993; 62:397-405.

Rathmell JC, Thompson CB. Pathways of apoptosis in lymphocyte development, homeostasis, and disease. Cell 2002; 109:S97-107.

Ravid A, Koren R, Rotem C, Garach-Jehoshua 0, Glaser T, Liberman UA. 1,25-Dihydroxyvitamin D3 increases the cellular content of the calcium-activated neutral protease mu-calpain in renal cell carcinoma. Endocrinology 1994; 135:2822-5.

Reed JC. Apoptosis-regulating proteins as targets for drug discovery. Trends Mol Med 2001; 7:314-9.

Roberg K, Kagedal K, Ollinger K Microinjection of cathepsin D induces caspase-dependent apoptosis in fibroblasts. Am J Pathol 2002; 161:89-96.

Robert-Lewis JM, Marcy VR, Zhao Y, Vaught JL, Siman R, Lewis ME. Aurintricarboxylic acid protects hippocampal neurons from N MDAand ischemia-induced toxicity in vivo. J Neurochem 1993; 61:37881.

Roberts LR, Adjei PN, Gores GJ. Cathepsins as effector proteases in hepatocyte apoptosis. Cell Biochem Biophys 1999; 30:71-88.

Ruiz-Vela A, Gonzalez de Buitrago G, Martinez-AC. Implication of calpain in caspase activation during $B$ cell clonal deletion. EMBO J 1999:18:4988-98.

Sakahira H, Iwamatsu A, Nagata S. Specific chaperone-like activity of inhibitor of caspase-activated DNase for caspase-activated DNase. J Biol Chem 2000; 275:8091-6.

Salvesen GS, Dixit VM. Caspases: intracellular signaling by proteolysis. Cell 1997; 91:443-6. 
Saraste A, Pulkki K. Morphologic and biochemical hallmarks of apoptosis. Cardiovasc Res 2000; 45:528-37.

Sarin A, Adams DH, Henkart PA. Protease inhibitors selectively block $T$ cell receptor-triggered programmed cell death in murine $T$ cell hybridomas and activated peripheral T cells. J Exp Med 1993; 178:1693-1700.

Sarin A, Clerici M, Blatt SP, Hendrix CW, Shearer GM, Henkart PA. Inhibition of activation-induced programmed cell death and restoration of defective immune responses of HIV+ donors by cysteine protease inhibitors. J Immunol 1994; 153:862-72.

Sarin A, Haddad EK, Henkart PA. Caspase dependence of target cell damage induced by cytotoxic lymphocytes. J Immunol 1998; 161:2810-6.

Schwartz DC, Cantor CR. Separation of yeast chromosome-sized DNAs by pulse field gradient gel electrophoresis. Cell 1984; 37:6774.

Scovassi AI, Poirier GG. Poly(ADP-ribosylation) and apoptosis. Mol Cell Biochem 1999; 199:125-37.

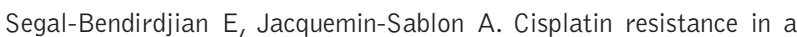
murine leukemia cell line is associated with a defective apoptotic process. Exp Cell Res 1995; 218:201-12.

Segal-Bendirdjian E, Jacquemin-Sablon A. Cisplatin resistance in a murine leukemia cell line associated with defect of apoptosis. Bull Cancer 1996; 83:371-8.

Shi L, Kraut RP, Aebersold R, Greenberg AH. A natural killer cell granule protein that induces DNA fragmentation and apoptosis. J Exp Med 1992; 175:553-66.

Shiokawa D, Tanuma S. Molecular cloning and expression of a cDNA encoding an apoptotic endonuclease DNase gamma. Biochem $J$ 1998a; 332:713-20.

Shiokawa D, Tanuma S. Cloning of cDNAs encoding porcine and human DNase II. Biochem Biophys Res Commun 1998b; 247:864-9.

Shiokawa D, Tanuma S. Characterization of human DNase I family endonucleases and activation of DNase gamma during apoptosis. Biochemistry 2001; 40:143-52.

Small GW, Chou TY, Dang CV, Orlowski RZ. Evidence for involvement of calpain in C-Myc proteolysis in vivo. Arch Biochem Biophys 2002; 400:151-61.

Soldani C, Bottone MG, Pellicciari C, Scovassi AI. Two-color fluorescence detection of Poly (ADP-Ribose) Polymerase-1 (PARP-1) cleavage and DNA strand breaks in etoposide-induced apoptotic cells. Eur J Histochem 2001; 45: 389-92

Soldani C, Scovassi AI. Poly(ADP-ribose) polymerase-1 cleavage during apoptosis: An update. Apoptosis 2002; 7:321-8.

Spencer MJ, Mellgren RL. Overexpression of a calpastatin transgene in mdx muscle reduces dystrophic pathology. Hum Mol Genet 2002; 11:2645-55.

Squier MK, Cohen JJ. Calpain, an upstream regulator of thymocite apoptosis. J Immunol 1997; 158:3690-7.

Squier MK, Miller AC, Malkinson AM, Cohen JJ. Calpain activation in apoptosis. J Cell Physiol 1994; 159:229-37.

Squier MK, Sehnert AJ, Sellins KS, Malkinson, AM, Takano E, Cohen JJ. Calpain and calpastatin regulate neutrophil apoptosis. J Cell Physiol 1999; 178:311-9.

Stoka V, Turk B, Schendel SL, Kim T, Cirman T, Snipas SJ et al. Lysosomal protease pathways to apoptosis. Cleavage of bid, not procaspases, is the most likely route. J Biol Chem 2001; 276:3149-57.

Sutton VR, Davis JE, Cancilla M, Johnstone RW, Ruefli AA, Sedeklies $\mathrm{K}$ et al. Initiation of apoptosis by granzyme $\mathrm{B}$ requires direct cleavage of bid, but not direct granzyme B-mediated caspase activation. J Exp Med 2000; 192:1403-14.

Tamm I, Schriever F, Dörken B. Apoptosis: implications of basic research for clinical oncology. Lancet 2001; 2:33-42.

Tewari M, Quan LT, O'Rourke K, Desnoyers S, Zeng Z, Beidler DR, et al. Yama/C PP32 beta, a mammalian homolog of CED-3, is a CrmAinhibitable protease that cleaves the death substrate poly(ADP- ribose) polymerase. Cell 1995; 81:801-9.

Thornberry NA, Lazebnik Y. Caspases: enemies within. Science 1998; 281:1312-6.

Torriglia A, Chaudun E, Chany-Fournier F, Jeanny JC, Courtois Y, Counis MF. Involvement of DNase II in nuclear degeneration during lens cell differentiation. J Biol Chem 1995; 270:28579-85.

Torriglia A, Perani P, Brossas JY, Chaudun E, Treton J, Courtois $Y$ et al. L-DNase II, a molecule that links proteases and endonucleases in apoptosis, derives from the ubiquitous serpin leukocyte elastase inhibitor. Mol Cell Biol 1998; 18:3612-9.

Torriglia A, Negri C, Chaudun E, Prosperi E, Courtois Y, Counis MF et al. Differential involvement of DNase II in HeLa cell apoptosis induced by etoposide and long term culture. Cell Death Differ. 1999; 6: 234-44.

Trambas CM, Griffiths GM. Delivering the kiss of death. Nature Immunol 2003; 4:399-403.

Tsukuba T, Okamoto K, Yasuda Y, Morikawa W, Nakanishi H, Yamamoto K. New functional aspects of cathepsin $D$ and cathepsin E. Mol Cells 2000; 10:601-11.

Turk B, Turk D, Tiìurk V. Lysosomal cysteine proteases: more than scavengers. Biochim Biophys Acta 2000; 1477:98-111.

Uchiyama Y. Autophagic cell death and its execution by lysosomal cathepsins. Arch Histol Cytol 2001; 64:233-46.

Vaux DL, Korsmeyer SJ. Cell death in development. Cell 1999; 96:245-54.

Walker PR, Sikorska M. New aspects of the mechanism of DNA fragmentation in apoptosis. Biochem Cell Biol 1997; 75:287-99.

Wang CC, Lu SC, Chen HL, Liao TH. Porcine spleen deoxyribonuclease II. Covalent structure, CDNA sequence, molecular cloning, and gene expression. J Biol Chem 1998; 273:17192-8.

Wright SC, Schellenberger U, Wang H, Kinder DH, Talhouk JW et al. Activation of CPP32-like proteases is not sufficient to trigger apoptosis: inhibition of apoptosis by agents that suppress activation of AP24, but not CPP32-like activity. J Exp Med 1997; 186:1107-17.

Wright SC, Schellenberger $U$, Wang $H$, Wang $Y$, Kinder DH. Chemotherapeutic drug activation of the AP24 protease in apoptosis: requirement for caspase 3-like-proteases. Biochem Biophys Res Commun 1998a; 245:797-803.

Wright SC, Wang H, Wei QS, Kinder DH, Larrick JW. Bcl-2-mediated resistance to apoptosis is associated with glutathione-induced inhibition of AP24 activation of nuclear DNA fragmentation. Cancer Res 1999b; 58:5570-6.

Wyllie AH. Glucocorticoid-induced thymocyte apoptosis is associated with endogenous endonuclease activation. Nature 1980:284:555-6.

Wyllie AH, Kerr JF, Currie AR. Cell death: the significance of apoptosis. Int Rev Cytol 1980; 68:251-306.

Yakovlev AG, Wang G, Stoica BA, Simbulan-Rosenthal CM, Yoshihara $\mathrm{K}$, Smulson ME Role of DNAS1L3 in $\mathrm{Ca} 2$ +and $\mathrm{Mg} 2+$-dependent cleavage of DNA into oligonucleosomal and high molecular mass fragments. Nucl Acids Res 1999; 27:1999-2005.

Yakovlev AG, Wang G, Stoica BA, Boulares HA, Spoonde AY, Yoshihara $\mathrm{K}$ et al. A role of the $\mathrm{Ca} 2+/ \mathrm{Mg} 2+-$ dependent endonuclease in apoptosis and its inhibition by poly(ADP-ribose) polymerase. $\mathrm{J}$ Biol Chem 2000; 275:21302-8.

Yasuda T, Takeshita H, Iida R, Nakajima T, Hosomi 0, Nakashima $Y$ et al. Molecular cloning of the cDNA encoding human deoxyribonuclease II. J Biol Chem 1998; 273:2610-6.

Zhang J, Wang X, Bove KE, Xu M. DNA fragmentation factor 45-deficient cells are more resistant to apoptosis and exhibit different dying morphology than wild-type control cells. J Biol Chem 1999; 274:37450-4.

Zhang J, Xu M. Apoptotic DNA fragmentation and tissue homeostasis. Trends Cell Biol 2002; 12:84-9. 